\title{
$\mu$-Opioid Receptors within Subregions of the Striatum Mediate Pair Bond Formation through Parallel Yet Distinct Reward Mechanisms
}

\author{
Shanna L. Resendez, ${ }^{1}$ Mackenzie Dome, ${ }^{2}$ Gwen Gormley, ${ }^{2}$ Dena Franco, ${ }^{2}$ Natalie Nevárez, ${ }^{2}$ Arif A. Hamid, \\ and Brandon J. Aragona ${ }^{1,2}$ \\ ${ }^{1}$ Neuroscience Graduate Program and 2Department of Psychology, University of Michigan, Ann Arbor, Michigan 48109
}

\begin{abstract}
The prairie vole is a socially monogamous rodent that is an excellent animal model for studies of the neurobiology of social attachment. Such studies have demonstrated that activation of reward circuitry during social interactions facilitates pair bond formation. Within this circuitry, $\mu$-opioid receptors (MORs) modulate naturally rewarding behavior in an anatomically segregated manner; MORs located throughout the striatum (dorsal striatum, NAc core, and the entire NAc shell) are implicated in general motivational processes, whereas those located specifically within the dorsomedial NAc shell mediate positive hedonics (and are referred to as a "hedonic hotspot"). The purpose of the present study was to determine whether MORs within these distinct subregions differentially mediate pair bond formation. We first used receptor autoradiography to compare MOR binding densities between these regions. MOR binding was significantly higher in the NAc core and dorsomedial NAc shell compared with the ventral NAc shell. We next used partner preference testing to determine whether MORs within these subregions differentially mediate pair bonding. Blockade of MORs using 1 or $3 \mu \mathrm{g}$ of H-D-PheCys-Tyr-D-Trp-Arg-Thr-Pen-Thr-NH ${ }_{2}$ within the dorsal striatum decreased mating during the cohabitation period and inhibited partner preference formation. In contrast, blockade of MORs within dorsomedial NAc shell inhibited partner preference formation without effecting mating behavior, whereas other regions were not involved. Thus, MORs within the dorsal striatum mediate partner preference formation via impairment of mating, whereas those in the dorsomedial NAc shell appear to mediate pair bond formation through the positive hedonics associated with mating.
\end{abstract}

\section{Introduction}

The socially monogamous prairie vole (Microtus ochrogaster) is an excellent animal model for studying the neurobiology of social attachment (Young et al., 2005). Prairie vole mating partners form selective pair bonds that begin with an initial preference for a mating partner. This "partner preference" is associated with positive social interactions (Williams et al., 1992; Winslow et al., 1993) that are regulated by reward circuitry (Aragona and Wang, 2009). Importantly, this circuitry is partly comprised of hedonic processing systems that code the valence of environmental stimuli and, together, coordinate goal-seeking behaviors (Dickinson and Balleine, 2010; Leknes and Tracey, 2010). For example, positive hedonics is important for appetitive behavior (Cacioppo et al., 2004; Watson et al., 2010), including that of a social nature

\footnotetext{
Received Aug. 28, 2012; revised April 16, 2013; accepted April 16, 2013.

Author contributions: S.L.R. and B.J.A. designed research;S.L.R., M.D., and N.N. performed research;S.L.R., G.G., D.F., N.N., and A.A.H. analyzed data; S.L.R. and B.J.A. wrote the paper.

This work was supported by the National Science Foundation Grant 0953106 to B.J.A. and Rackham Merit Fellowship to S.L.R. We thank Yan Liu for assistance with the opioid receptor autoradiography, Kirsten Porter-Stransky for statistical consultation, Piper Keyes for brain slicing, and Zouxin Wang for the generous donation of meadow voles.

The authors declare no competing financial interests.

Correspondence should be addressed to either Brandon J. Aragona or Shanna L. Resendez, Department of Psychology, University of Michigan, Ann Arbor, MI 48109, E-mail: aragona@umihc.edu or slharkey@umich.edu.

DOI:10.1523/JNEUROSCI.4123-12.2013

Copyright $@ 2013$ the authors $\quad 0270-6474 / 13 / 339140-10 \$ 15.00 / 0$
}

(Komisaruk et al., 2010). An essential neural mechanism for mediating positive hedonics is the activation of $\mu$-opioid receptors (MORs) (Panksepp et al., 1980; Bakshi and Kelley, 1993; Pecina and Berridge, 2000) within the dorsomedial portion of the nucleus accumbens (NAc) shell (i.e., a hedonic hotspot), a subportion of the striatum with distinct functional/anatomical characteristics (Pecina and Berridge, 2005; Britt and McGehee, 2008; Smith et al., 2010; Britt et al., 2012; Watabe-Uchida et al., 2012).

Although neural regulators of reward are commonly hypothesized to mediate appetitive social behavior (Trezza et al., 2011), "reward" is not a unitary psychological concept; it has been suggested that "reward" may encompass at least three psychological components: hedonics, motivation, and learning (Berridge and Robinson, 2003). Importantly, studies of food reward have identified that MORs distributed throughout the striatum mediate motivational and hedonic components of food reward in an anatomically segregated manner (Kelley and Berridge, 2002). Specifically, stimulation of MORs throughout the striatum (dorsal striatum, NAc core, and the entire NAc shell) increases general motivational state (Bakshi and Kelley, 1993; Zhang and Kelley, 2000; DiFeliceantonio et al., 2012), whereas only stimulation of MORs within the dorsomedial NAc shell mediates the positive hedonic responses associated with the consumption of highly palatable foods (Kelley et al., 2005; Pecina and Berridge, 2005; Smith and Berridge, 2007). This anatomical framework can be used as a tool to test the neurochemical and neuroana- 
A

Representative Example of Rostral Striatum

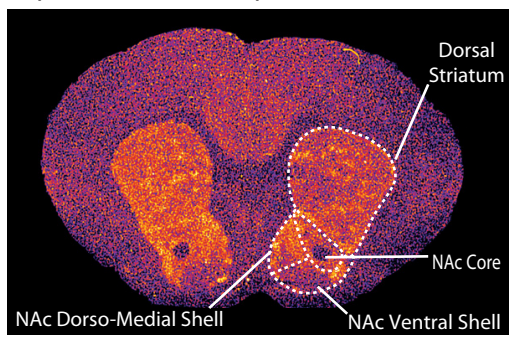

C

Average of rostral Striatum

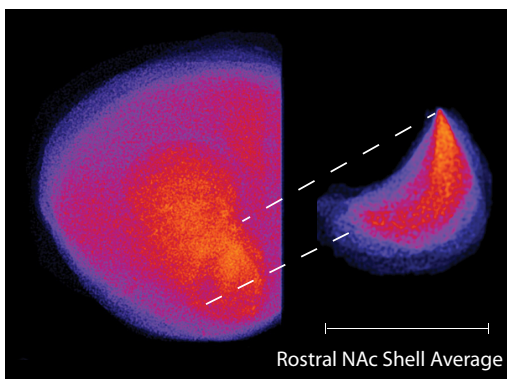

E

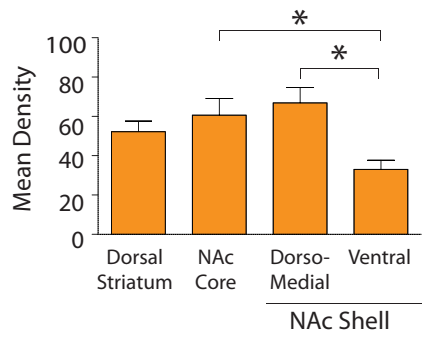

G

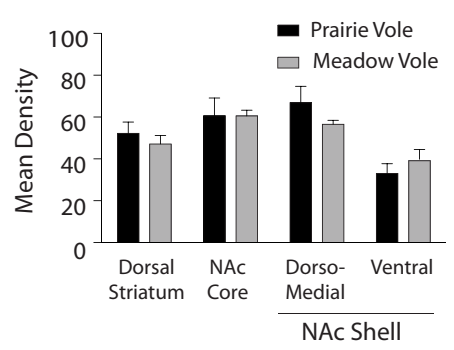

B

Representative Example of Caudal Striatum

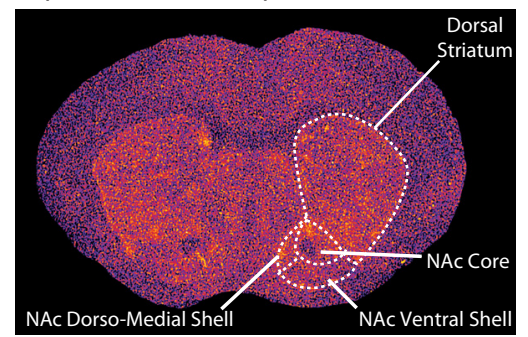

D

Average oi Caudal Striatum

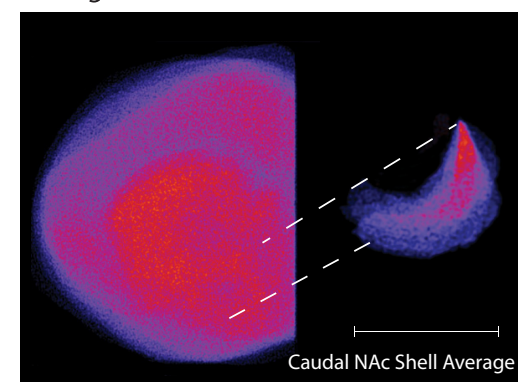

$\mathrm{F}$

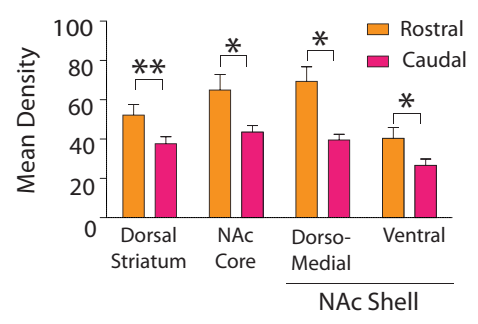

$\mathrm{H}$

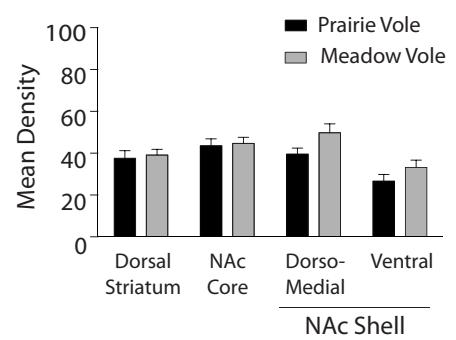

Figure 1. MOR binding within the striatum. $\boldsymbol{A}$, Left, Representative image of MOR binding density within the rostral striatum. $\boldsymbol{B}$, Right, Representative image of MOR bonding within the caudal striatum. On the right side of each image, we outline the regions analyzed to obtain mean MOR binding density. C, A composite image of the rostral shell of female prairie voles. $\boldsymbol{D}$, The caudal shell. $\boldsymbol{E}$, In the rostral striatum, MOR binding was significantly higher in the NAc core and dorsomedial NAc shell compared with the ventral NAc shell $(n=5)$. $\boldsymbol{F}$, MOR binding was higher in all regions in the rostral striatum compared with the caudal striatum ( $n=$ 5). $\boldsymbol{G}, \boldsymbol{H}$, There was no difference in MOR binding density between prairie and meadow voles in $(\boldsymbol{G})$ rostral or $(\boldsymbol{H})$ caudal regions of the striatum $(n=5) .{ }^{*} p \leq 0.05 .{ }^{* *} p \leq 0.005$.

tomical correlates that mediate other types of reward, such as attachment formation.

In the current study, we have used this well-established functional/anatomical mapping of MOR regulation of reward to determine whether specific subregions of the striatum, and therefore, possibly specific psychological components of reward, regulate partner preference formation. This study is especially important because it was recently suggested that MORs in the dorsal striatum, but not the NAc, are important for partner preference formation because blockade of MORs within dorsal striatum, but not within the ventral NAc shell, prevented partner preference formation (Burkett et al., 2011). However, this previous study did not examine the role of MORs within the dorsomedial NAc shell (i.e., the region critical for hedonics). Thus, in the present study, we used receptor autoradiography and site-directed behavioral pharmacology to compare the involvement of MORs within four regions of the striatum in partner preference formation.

\section{Materials and Methods}

Subjects. Subjects for partner preference tests were adult female prairie voles bred at the University of Michigan (Resendez et al., 2012). Adult male prairie voles were used as stimulus animals. Subjects were weaned and housed as previously described (Resendez et al., 2012). All procedures were conducted in accordance with the animal care guidelines of the University of Michigan. Adult female prairie and meadow voles used for MOR autoradiography were bred at Florida State University in the laboratory of Dr. Zouxin Wang, and all procedures were conducted in accordance with Florida State University animal care guidelines.

Receptor autoradiography. Subjects were killed via rapid decapitation, and brains of sexually naive female prairie $(n=5)$ and sexually naive female meadow voles $(n=5)$ were removed, immediately frozen on dry ice, and stored at $-80^{\circ} \mathrm{C}$ (Aragona et al., 2006; Lim et al., 2006; Resendez et al., 2012). Brains were sectioned on a cryostat at $15 \mu \mathrm{m}$ in four serial sections and stored at $-80^{\circ} \mathrm{C}$ until processing (Liu et al., 2010). MOR autoradiography (DAMGO; PerkinElmer, catalog \#NET 902; lot \#3615807) was conducted as previously described (Resendez et al., 2012). Kodak BioMAx MS film was laid on the slides and exposed for 6 months (Resendez et al., 2012). After completion of the exposure period, film images were captured using a Scan Maker 1000XL Microtek scanner. The density of MOR binding within the dorsal striatum, the NAc core, the dorsomedial NAc shell, and the ventral NAc shell (Fig. $1 A, B$ ) was analyzed with NIH Image 64 (Bales et al., 2007b). MOR binding densities within each region were measured in four serial rostral coronal sections (before the corpus callosum fusing) (Aragona et al., 2006) as well as four serial coronal sections caudal to the callosum fusions (when the anterior commissure is aligned with the ventricle). These rostral and caudal regions were averaged for each respective region of the striatum.

The above anatomical markers of rostral and caudal striatum were chosen to be consistent with those that have been previously described in voles (Aragona et al., 2006) as well as those that are currently used to describe the location of the NAc hedonic hotspot in rats (Richard et al., 
Table 1. Ratio of subjects that mated per treatment group ${ }^{a}$

\begin{tabular}{lll}
\hline & Mated $(n)$ & No \\
\cline { 2 - 3 } Group & Yes & 3 \\
\hline aCSF & 11 & 3 \\
$\begin{array}{l}\text { Dorsal striatum } \\
1 \mu g \text { CTAP }\end{array}$ & 10 & 6 \\
$\begin{array}{l}3 \mu \mathrm{g} \text { CTAP } \\
\text { NAc core }\end{array}$ & 6 & 3 \\
$1 \mu \mathrm{g}$ CTAP & 6 & 3 \\
$3 \mu \mathrm{g}$ CTAP & 5 & 1 \\
NAc dorsomedial shell & & 2 \\
$1 \mu \mathrm{g}$ CTAP & 8 & 1 \\
$3 \mu \mathrm{g}$ CTAP & 4 & 2 \\
NAc ventral shell & & \\
$1 \mu \mathrm{g}$ CTAP & 9 & \\
$3 \mu \mathrm{g}$ CTAP & 8 & \\
\hline
\end{tabular}

${ }^{a}$ Data are presented as $n$ per group. Site-specific blockade of MORS with 1 or $3 \mu \mathrm{g}$ CTAP into any region of the striatum did not impact the total number of animals that mated per treatment group.

2013). Mean densities of all regions of interest were background subtracted from white matter tracts (anterior commissure) (Olazabal and Young, 2006). ImageJ 64 was also used to generate composite images of the average MOR binding density of five female prairie voles within the rostral and caudal striatum (Fig. $1 C, D$ ). Images were made by stacking either the rostral or caudal sections used for analysis for each female prairie vole ( $n=20 ; 4$ sections/female) and then the binding density was averaged across the images.

Stereotaxic cannulation. Female prairie voles were anesthetized with a mixture of ketamine $(100 \mathrm{mg} / \mathrm{kg})$ and xylazine $(10 \mathrm{mg} / \mathrm{kg})$ and implanted with a 26-gauge bilateral guide cannula aimed at the dorsal striatum $(+1.6 \mathrm{~mm} \mathrm{~A} / \mathrm{P} ; \pm 1.5 \mathrm{~mm} \mathrm{M} / \mathrm{L} ;-3.0 \mathrm{~mm} \mathrm{D} / \mathrm{V})$, NAc core $(+1.6 \mathrm{~mm}$ $\mathrm{A} / \mathrm{P} ; \pm 1.2 \mathrm{~mm} \mathrm{M} / \mathrm{L} ;-3.5 \mathrm{~mm} \mathrm{D} / \mathrm{V})$, or NAc shell $(+1.7 \mathrm{~mm} \mathrm{~A} / \mathrm{P}$; $\pm 1 \mathrm{~mm} \mathrm{M} / \mathrm{L}$; dorsomedial: $-4.2 \mathrm{~mm} \mathrm{D} / \mathrm{V}$; ventral: $-4.5 \mathrm{~mm} \mathrm{D} / \mathrm{V})$ (Aragona et al., 2003; Burkett et al., 2011). All subjects were administered $10 \mathrm{mg} / \mathrm{kg}$ ketoprophen immediately after surgery as well as $24 \mathrm{~h}$ later and were given 3-5 $\mathrm{d}$ to recover in their home cage with their cage mate.

Cohabitation and partner preference tests. MOR regulation of pair bond formation was examined using site-directed pharmacological manipulation of mating-induced partner preferences (Liu and Wang, 2003; Cushing et al., 2008). After surgery, female subjects were estrogen primed with $2.0 \mu \mathrm{g}$ estradiol benzoate for $3 \mathrm{~d}$ before cohabitation with a male (Fowler et al., 2005; Burkett et al., 2011). On the day of the experiment, artificial cerebral spinal fluid (aCSF) $(n=11)$ or aCSF containing 1 or $3 \mu \mathrm{g}$ of the specific MOR antagonist H-D-Phe-Cys-Tyr-D-Trp-Arg-Thr-Pen-Thr$\mathrm{NH}_{2}$ (CTAP) (Sigma-Aldrich) (Burkett et al., 2011; Trezza et al., 2011) was infused into one of four regions of the striatum (dorsal striatum $n=6-10$; NAc core $n=5-6$; dorsomedial NAc shell: $n=4-8$; ventral NAc shell: $n=$ $8-9)$.

Immediately after injections, female subjects were placed in a cage with a novel male (referred to as the "partner") and allowed to cohabitate and mate for $24 \mathrm{~h}$, which reliably induces partner preference formation (Williams et al., 1992). The first $6 \mathrm{~h}$ of the cohabitation were analyzed for the total number of mating bouts, and only subjects who mated during this period were included in the study (Carter and Keverne, 2002; Aragona et al., 2003; Liu and Wang, 2003; Curtis and Wang, 2005a). A mating bout was described as the occurrence of the following sequence of events: mount, intromission, and grooming of the genital areas. Lordosis is required for the male to properly mount and intromit the female, and this behavior was also assessed during an individual bout. There was no difference in the total number of animals who mated between subjects who received CTAP into the dorsal striatum $\left(\chi^{2}=3.79, \mathrm{df}=2, p=0.15\right)$, the NAc core $\left(\chi^{2}=0.55, \mathrm{df}=2, p=0.76\right)$, or the NAc shell $\left(\chi^{2}=1.29, \mathrm{df}=\right.$ $4, p=0.86$ ) (Table 1 ). The first $10 \mathrm{~min}$ of each hour during this $6 \mathrm{~h}$ period were also scored to quantify the duration of affiliative behavior (olfactory investigation and side-by-side contact) as well as the frequency of locomotor activity (cage crosses) during the cohabitation period.

After the $24 \mathrm{~h}$ cohabitation period, partner preference testing was conducted using a modified partner preference apparatus (Ahern and
Young, 2009; Burkett et al., 2011). Briefly, the partner preference apparatus was composed of three equally sized compartments divided by partial barriers. Male partners were loosely tethered in one compartment, whereas novel males (referred to as "strangers") were loosely tethered in the opposite compartment (Donaldson et al., 2010; Keebaugh and Young, 2011). At the beginning of the test, the female subjects were placed in the center (neutral) compartment and allowed to freely roam between compartments for $3 \mathrm{~h}$ (Curtis et al., 2001; Bales et al., 2007a). A significant partner preference was determined by statistically comparing (see below) the duration of mean time spent in contact with the partners to the duration of time spent in contact with the strangers (Cho et al., 1999; Cushing et al., 2003; Bales et al., 2007a). Cannulae placements were confirmed by slicing frozen brains into $40 \mu \mathrm{m}$ sections using a Leica cryostat (CM1850). Only subjects with correct placements were used for analysis. All striatal placements were in rostral portions of the nuclei (i.e., regions previously proven to be important for pair bond formation) (Aragona et al., 2006).

Statistics. A one-way ANOVA was used to compare the densities of MORs between the four regions of the striatum (Heinz et al., 2005). A paired $t$ test was used to compare MOR binding density between the rostral and caudal portions of each region. A two-way ANOVA (species $\times$ region) was used to compare MOR binding density between prairie and meadow voles (Insel and Shapiro, 1992). A one-way ANOVA was used to compare differences in mating bouts between treatment groups as well as total contact time (partner contact + stranger contact) during the partner preference test (Burkett et al., 2011). A two-way ANOVA (treatment $\times$ time) was used to determine whether inhibition of MORs impacted affiliative behaviors or locomotor activity during the first $6 \mathrm{~h}$ of cohabitation (Curtis et al., 2001; Aragona et al., 2003). A two-way ANOVA (treatment $\times$ chamber) was also used to determine whether MOR blockade affected the time spent in each chamber of the partner preference apparatus. All ANOVAs were followed by a Tukey's post hoc test. A partner preference was determined with a paired $t$ test by comparing the duration of time spent in contact with the partner to that of the stranger (Cushing et al., 2003; Curtis and Wang, 2005a). Finally, a $\chi^{2}$ was used to compare the total number of subjects that mated within a treatment group. In all cases, statistical significance was determined using an $\alpha$ level of $\leq 0.05$.

\section{Results}

\section{Quantification of MOR binding throughout the striatum}

Previous studies have identified MORs within the dorsomedial NAc shell as important for positive hedonics (i.e., a "hedonic hotspot"), and it has been postulated that this may be associated with a higher density of MORs in this region (Pecina and Berridge, 2000; Smith and Berridge, 2007). In our previous study, we noticed (qualitatively) that prairie voles showed a higher density of MORs in the dorsomedial NAc shell (Resendez et al., 2012, their Fig. 6), and this is also evident in a recently paper published by another group (Burkett et al., 2011, their Fig. 4). In the present study, we provide the first quantification of MOR density across the striatum of female prairie voles (Fig. $1 A-D$ ) and demonstrate that MOR density varies by region $\left(F_{(3,19)}=4.70, p=0.02\right)$. Specifically, within rostral regions of the striatum, MOR binding within the dorsomedial NAc shell is significantly higher than the ventral NAc shell ( $p=$ 0.05 ; Fig. $1 E)$. MOR binding within the NAc core was also significantly higher than the ventral NAc shell $(p=0.01$; Fig. $1 E)$. The density of MOR binding did not significantly differ between any other regions of the striatum. Although MORs within the dorsal striatum were not significantly higher than the ventral striatum in this paper, it is important to note that this may be the result of variation in patch/matrix distribution because MOR density is very high in patches (or striosomes) and low in the matrix (Graybiel and Chesselet, 1984; Johnston et al., 1990; Gerfen, 1992).

MOR binding densities also varied along a rostral-caudal gradient. Within all regions of the striatum, the binding density was 
significantly higher in rostral regions compared with caudal portions: dorsal striatum $\left(t_{(4)}=4.69, p=0.009\right)$, NAc core $\left(t_{(4)}=\right.$ $3.41, p=0.03)$, dorsomedial NAc shell $\left(t_{(4)}=3.77, p=0.02\right)$, and ventral NAc shell $\left(t_{(4)}=3.48, p=0.03\right.$ ) (Fig. $\left.1 F\right)$. Together, these data demonstrate that, within the striatum, MOR binding density is significantly higher within the rostral regions. Moreover, within the NAc shell, MOR binding density is highest within rostral dorsomedial region (Fig. 1C,D).

To determine whether there are any differences in striatal MOR binding density between monogamous and nonmonogamous vole species, we compared MOR binding density between female prairie voles and female meadow voles, a nonmonogamous vole species (Beery and Zucker, 2010). This comparison was made because previous studies have identified relationships between receptor binding patterns and the social organizations of a vole species (Insel and Shapiro, 1992; Insel et al., 1994; Wang et al., 1997; Young et al., 1997, 1999; Lim and Young, 2004; Aragona et al., 2006; Barrett et al., 2013). Similar to above, MOR binding was measured in the dorsal striatum, the NAc core, the dorsomedial NAc shell, and the ventral NAc shell. Consistent with previous studies (Insel and Shapiro, 1992), there were no species differences in binding density between any regions of the rostral striatum $\left(F_{(2,32)}=0.41, p=0.53\right.$; Fig. $\left.1 G\right)$. Within the caudal striatum, the overall ANOVA for MOR binding was significant $\left(F_{(2,32)}=4.12, p=0.05\right)$, but post hoc test did not reveal any specific species differences between any region of the striatum (Fig. $1 H$ ).

The consistent binding pattern of these receptors across vole species suggests that MORs within the striatum do not play a direct role in species-specific social organization but rather appear to play a more general role in natural reward processing. Consistent with this, within the NAc of other species, a high density of MOR binding can be seen in the dorsomedial NAc shell of the rat (Herkenham et al., 1984) and MOR binding within the human NAc shell is also reported to be highly heterogeneous (Voorn et al., 1996), further suggesting that MORs within specific striatal regions may act as a common neural currency of reward. To test whether MORs are important for social reward and, therefore important for social bonding, we conducted a thorough analysis of MORs throughout the striatum for their role in pair bond formation.

\section{MORs and partner preference formation Dorsal striatum}

It was recently demonstrated that blockade of MORs in the dorsal striatum with $1 \mu \mathrm{g}$ CTAP prevented the formation of partner preferences in female prairie voles (Burkett et al., 2011). Therefore, we first set out to replicate this finding. As previously described (Burkett et al., 2011), control females that received aCSF showed significant partner preferences $\left(t_{(10)}=2.895, p=0.02\right.$; Fig. $2 A$ ). Further, we also replicated this study by demonstrating that blockade of MORs within the dorsal striatum with CTAP inhibits partner preference formation (Burkett et al., 2011), although our dose-response differed. Specifically, we did not replicate the finding that blockade of MORs within the dorsal striatum with $1 \mu \mathrm{g}$ CTAP inhibits partner preference formation $\left(t_{(8)}=3.34, p=0.01\right.$; Fig. $\left.2 A\right)$. However, the higher dose of CTAP $(3 \mu \mathrm{g})$ used in the present study prevented partner preference formation $\left(t_{(5)}=0.72, p=0.50\right.$; Fig. $\left.2 A\right)$. Blockade of MORs in the dorsal striatum did not affect the total contact time $\left(F_{(2,26)}=\right.$ $2.38, p=0.114$; Fig. $2 C)$ or the amount of time spent in each chamber $\left(F_{(2,72)}=9.41, p=0.97\right.$; Fig. $\left.2 B\right)$ during the partner preference test. Thus, our overall finding that blockade of MORs
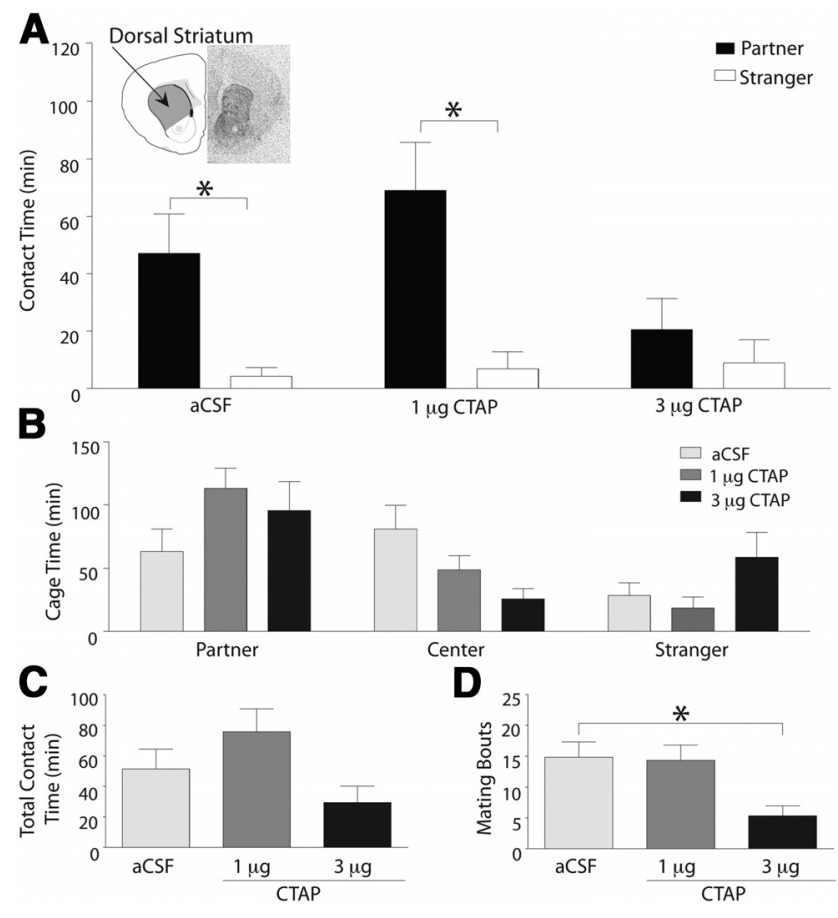

Figure 2. MORs within the dorsal striatum regulate pair bond formation via inhibition of mating. $A$, Injections of aCSF or the low dose of CTAP into the dorsal striatum did not inhibit partner preference formation, whereas injections of the high dose of CTAP into this region abolished partner preference. Inset, Site of injection shaded in gray (left) and the binding of MOR within the dorsal striatum (right). $\boldsymbol{B}-\boldsymbol{D}$, MOR blockade did not affect $(\boldsymbol{B})$ cage time or $(\boldsymbol{C})$ total contact time (i.e., time spent in contact with the partner + the stranger) during the partner preference test. However, blockade of MORs with the high dose of (TAP decreased the (D) total number of mating bouts during the cohabitation period $(n=6-10) .{ }^{*} p \leq 0.05$.

within the dorsal striatum inhibits partner preference formation is consistent with that published in a previous report (Burkett et al., 2011), and the difference in effective dose may be the result of slight variations in probe placement (Fig. 5), especially given the variation in patch/matrix activation (Graybiel, 1990; Gerfen, 1992) (Fig. 2A, inset), or it is always possible for there to be slight differences between subjects from two different colonies.

Importantly, blockade of MORs in the dorsal striatum significantly decreased the total number of mating bouts during the habituation period $\left(F_{(2,26)}=3.58, p=0.04\right.$; Fig. $\left.2 D\right)$ without affecting the level of affiliative social interactions during the habituation period $\left(F_{(2,120)}=0.97, p=0.40\right.$; Table 2). Post hoc tests revealed that subjects who received the high dose of CTAP into the dorsal striatum mated significantly less than control subjects $(p=0.05$; Fig. $2 D)$. Importantly, MOR regulation over prairie vole mating behavior is consistent with a previous study (Burkett et al., 2011); and because mating is important for partner preference formation, these data suggest that administration of a dose of CTAP into the dorsal striatum that attenuates mating is the mechanism by which partner preference formation is disrupted. This decrease in mating behavior is not secondary to a general decrease in motor activity as blockade of MORS in the dorsal striatum had no effect on locomotor activity during the habituation period $\left(F_{(2,120)}=1.37, p=0.27\right.$; Table 3$)$.

\section{NAc core}

We next tested a possible role for MORs within the NAc core in partner preference formation (Fig. 5). Blockade of MORs within the NAc core with either the low $\left(t_{(5)}=3.07, p=0.03\right)$ or high $\left.t_{(5)}=3.07, p=0.03\right)$ dose of CTAP did not inhibit partner 
Table 2. Affiliative behavior during the cohabitation period ${ }^{a}$

\begin{tabular}{|c|c|c|c|c|c|c|}
\hline \multirow[b]{2}{*}{ Group } & \multicolumn{6}{|l|}{ Hour } \\
\hline & 1 & 2 & 3 & 4 & 5 & 6 \\
\hline $\mathrm{aCSF}$ & $1.71 \pm 0.60$ & $2.14 \pm 0.77$ & $1.83 \pm 0.50$ & $5.21 \pm 0.95$ & $2.80 \pm 0.93$ & $3.94 \pm 1.07$ \\
\hline \multicolumn{7}{|l|}{ Dorsal striatum } \\
\hline $1 \mu \mathrm{g} \mathrm{CTAP}$ & $1.43 \pm 0.42$ & $3.15 \pm 1.04$ & $4.15 \pm 1.29$ & $3.64 \pm 1.29$ & $4.81 \pm 1.56$ & $6.12 \pm 1.35$ \\
\hline $3 \mu \mathrm{g} \mathrm{CTAP}$ & $2.08 \pm 0.68$ & $3.13 \pm 1.55$ & $3.03 \pm 1.40$ & $2.94 \pm 0.96$ & $3.40 \pm 1.27$ & $5.49 \pm 1.03$ \\
\hline \multicolumn{7}{|l|}{ NAc core } \\
\hline $1 \mu \mathrm{g} \mathrm{CTAP}$ & $1.58 \pm 0.63$ & $1.08 \pm 0.51$ & $2.75 \pm 2.17$ & $2.6 \pm 1.09$ & $6.40 \pm 1.51$ & $3.18 \pm 0.99$ \\
\hline $3 \mu \mathrm{g}$ CTAP & $1.01 \pm 0.64$ & $1.14 \pm 0.55$ & $3.11 \pm 1.83$ & $3.55 \pm 1.67$ & $3.94 \pm 2.12$ & $3.56 \pm 1.64$ \\
\hline \multicolumn{7}{|c|}{ NAc dorsomedial shell } \\
\hline $1 \mu \mathrm{g} \mathrm{CTAP}$ & $1.97 \pm 0.43$ & $2.17 \pm 1.23$ & $0.22 \pm 0.10$ & $3.20 \pm 1.40$ & $4.27 \pm 1.48$ & $4.12 \pm 1.40$ \\
\hline $3 \mu \mathrm{g}$ CTAP & $1.54 \pm 0.59$ & $2.07 \pm 1.09$ & $2.83 \pm 1.59$ & $2.38 \pm 1.65$ & $3.37 \pm 1.11$ & $7.10 \pm 1.53$ \\
\hline \multicolumn{7}{|l|}{ NAc ventral shell } \\
\hline $1 \mu \mathrm{g} \mathrm{CTAP}$ & $2.15 \pm 0.84$ & $1.43 \pm 0.59$ & $2.41 \pm 1.09$ & $2.05 \pm 1.21$ & $3.45 \pm 1.55$ & $3.83 \pm 1.35$ \\
\hline $3 \mu \mathrm{g}$ CTAP & $1.20 \pm 0.44$ & $2.00 \pm 0.93$ & $4.12 \pm 1.34$ & $1.93 \pm 0.95$ & $5.96 \pm 0.74$ & $6.66 \pm 1.26$ \\
\hline
\end{tabular}

${ }^{a}$ Data are mean \pm SEM. Site-specific blockade of MORs with 1 or $3 \mu \mathrm{g}$ CTAP into any region of the striatum did not impact the duration of time (min) that female subjects spent engaging in affiliative behavior with the partner at each 10 min interval sampled during the first $6 \mathrm{~h}$ of cohabitation.

Table 3. Locomotor activity during the cohabitation period ${ }^{a}$

\begin{tabular}{|c|c|c|c|c|c|c|}
\hline \multirow[b]{2}{*}{ Group } & \multicolumn{6}{|l|}{ Hour } \\
\hline & 1 & 2 & 3 & 4 & 5 & 6 \\
\hline $\mathrm{aCSF}$ & $13.00 \pm 2.78$ & $11.25 \pm 1.27$ & $5.67 \pm 1.61$ & $4.83 \pm 1.20$ & $5.67 \pm 1.24$ & $3.83 \pm 1.22$ \\
\hline $3 \mu \mathrm{g} \mathrm{CTAP}$ & $17.43 \pm 3.82$ & $7.57 \pm 2.36$ & $9.29 \pm 3.23$ & $7.86 \pm 1.72$ & $4.23 \pm 2.20$ & $5.57 \pm 2.11$ \\
\hline \multicolumn{7}{|l|}{ NAc core } \\
\hline $1 \mu \mathrm{g} \mathrm{CTAP}$ & $7.5 \pm 1.55$ & $5.00 \pm 2.12$ & $7.25 \pm 3.35$ & $7.75 \pm 0.48$ & $6.00 \pm 2.48$ & $2.00 \pm 1.15$ \\
\hline $1 \mu \mathrm{g} \mathrm{CTAP}$ & $18.22 \pm 4.93$ & $7.89 \pm 2.50$ & $6.22 \pm 0.97$ & $7.00 \pm 3.23$ & $3.29 \pm 1.60$ & $8.86 \pm 4.40$ \\
\hline $3 \mu \mathrm{g} \mathrm{CTAP}$ & $11.40 \pm 0.68$ & $6.60 \pm 1.60$ & $3.20 \pm 1.24$ & $5.60 \pm 1.40$ & $0.80 \pm 0.49$ & $1.20 \pm 0.73$ \\
\hline \multicolumn{7}{|l|}{ NAc ventral shell } \\
\hline $1 \mu \mathrm{g} \mathrm{CTAP}$ & $17.33 \pm 5.67$ & $13.89 \pm 5.25$ & $8.44 \pm 4.07$ & $7.88 \pm 1.98$ & $8.38 \pm 2.96$ & $6.25 \pm 4.18$ \\
\hline $3 \mu \mathrm{g} \mathrm{CTAP}$ & $12.11 \pm 0.89$ & $8.78 \pm 0.97$ & $3.33 \pm 1.57$ & $4.89 \pm 1.24$ & $3.33 \pm 1.00$ & $1.00 \pm 0.71$ \\
\hline
\end{tabular}

a data are mean \pm SEM. Site-specific blockade of MORs with 1 or $3 \mu \mathrm{g}$ CTAP into any region of the striatum did not impact locomotor activity as measured by cage cross frequency during each 10 min interval sampled during the first $6 \mathrm{~h}$ of cohabitation.

preference formation (Fig. 3A). There was also no overall effect on the time spent in each chamber $\left(F_{(2,57)}=0.03, p=0.97\right.$; Fig. $3 B)$ or total contact time $\left(F_{(2,21)}=0.18, p=0.88\right.$; Fig. $\left.3 C\right)$ during the partner preference test. During the cohabitation period, there was also no effect on affiliative behavior $\left(F_{(2,108)}=0.06, p=0.94\right.$; Table 2$)$ or locmotor activity $\left(F_{(2,108)}=0.87, p=0.43\right.$; Table 3$)$. The overall ANOVA indicated a trend for a decrease in mating behavior $\left(F_{(2,21)}=3.00, p=0.07\right.$; Fig. $\left.3 D\right)$, and the lack of significance may be the result of the high level of variability in mating behavior in subjects treated with the low dose of CTAP $(1 \mu \mathrm{g})$. A $t$ test was therefore conducted to directly compare the mating bout frequency between control subjects and subjects treated with 1 or $3 \mu \mathrm{g}$ CTAP. There was no difference in the number of mating bouts between control females and those treated with $1 \mu \mathrm{g}$ CTAP $\left(t_{(15)}=0.22, p=0.83\right)$, but there was a significant difference between control females and those treated with $3 \mu \mathrm{g}$ CTAP $\left(t_{(14)} 2.94, p=0.01\right)$. To be consistent with the statistical analysis used on the rest of the treatment groups (and with those generally used to compare more than two groups), the overall data are reported as a trend, but it is important to note that the effect of MOR blockade within the NAc core appears to have variable effects on mating behavior and partner preference formation.

The inability of MOR blockade within the NAc core to significantly affect partner preference formation is consistent with previous studies of pair bonding that have not identified a role for the NAc core in this behavior (Aragona et al., 2006; Aragona and
Wang, 2007; Resendez et al., 2012). However, when the trend for a decrease in mating is considered in relation to the significant decrease in the dorsal striatum and lack of an effect on mating in the NAc shell (see below), the present data are consistent with the notion that the striatum is functionally connected via a ventromedial to dorsolateral spiraling system, which would make the NAc core a striatal transition zone between the NAc shell and dorsal striatum (Haber et al., 2000; Haber, 2003; Everitt and Robbins, 2005; Vanderschuren and Everitt, 2005). Therefore, MORs within this region may have intermediate effects on mating that are not sufficient to impact partner preference behavior. Intermediate pharmacological effects within the NAc core on partner preference behavior are consistent with the view that the striatum functions in a topographic manner, and intermediate effects on social reward behavior can be found in transition zones, such as the NAc core.

NAc shell

Previous studies have demonstrated that the NAc shell is a highly heterogeneous region (Ikemoto, 2007; Britt and McGehee, 2008; Resendez et al., 2012; Watabe-Uchida et al., 2012), especially in regards to function (Pecina and Berridge, 2005; Smith et al., 2010; Lammel et al., 2011; Britt et al., 2012; Richard et al., 2013). For example, the rostral dorsomedial NAc shell modulates positive hedonics, whereas the ventral NAc shell does not (Pecina and Berridge, 2005; Mahler et al., 2007; Faure et al., 2010; Smith et al., 2010). These regions are also anatomically distinct; they signifi- 
A
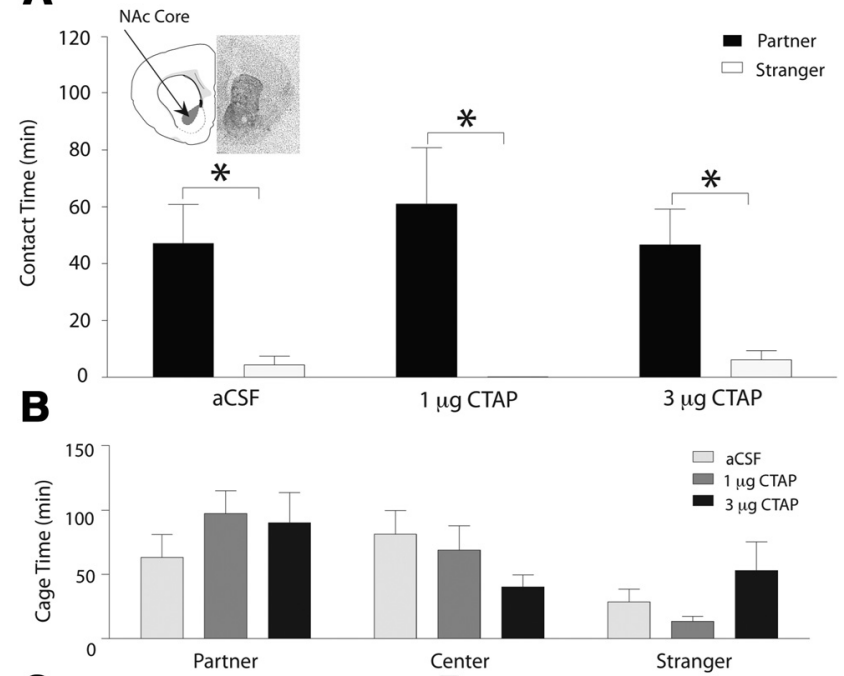

C

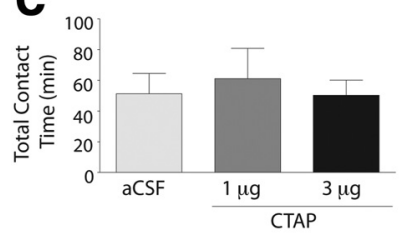

D

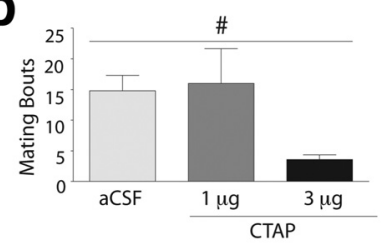

Figure 3. MORs within the NAc core do not play a significant role in partner preference formation. $\boldsymbol{A}$, Neither low nor high dose injections of CTAP into the NAc core impacted partner preference formation. Inset, Site of injection shaded in gray (left) and the binding of MOR within the NAc core (right). $\boldsymbol{B}-\boldsymbol{D}$, MOR blockade within the NAc did not have an effect on $(\boldsymbol{B})$ cage time or ( $\boldsymbol{C}$ ) total contact time (i.e., time spent in contact with the partner + the stranger) during the partner preference test, although there was a trend for a $(\boldsymbol{D})$ decrease in the number of mating bouts $(n=5$ or 6$) .{ }^{*} p \leq 0.05$ (trend). ${ }^{*} p=0.07$ (trend).

cantly differ in MOR binding, with the dorsomedial NAc shell having significantly greater binding compared with the ventral NAc shell (Burkett et al., 2011, their Fig. 1). Therefore, we next tested whether MORs within these subregions differentially regulate partner preferences (Fig. 5).

We first replicated a recent study (Burkett et al., 2011) by demonstrating that blockade of MORs within the ventral NAc shell with a low $\left(t_{(8)}=3.62, p=0.007\right)$ or high $\left(t_{(7)}=3.31, p=\right.$ 0.03 ) dose of CTAP did not influence partner preference formation (Fig. 4A). However, unlike the ventral NAc shell, blockade of MORs within the rostral dorsomedial NAc shell with either the low $\left(t_{(7)}=0.80, p=0.45\right)$ or high $\left(t_{(4)}=0.46, p=0.67\right)$ dose of CTAP abolished partner preference formation (Fig. $4 A$ ). This effect was not the result of drug effects on general social behavior or locomotor activity because blockade of MORs within any region of the NAc shell did not impact affiliative behavior $\left(F_{(4,180)}=0.81\right.$, $p=0.53$; Table 2) or locomotor activity during the cohabitation period $\left(F_{(4,180)}=0.90, p=0.48\right.$; Table 3$)$. During the partner preference test, there was no overall difference in the time spent in each chamber between treatment groups $\left(F_{(4,105)}=0.17, p=\right.$ 0.96 ; Fig. $4 B)$ or total contact time $\left(F_{(4,40)}=2.23, p=0.08\right.$; Fig. $4 C)$. Together, these data indicate that, within the NAc, MOR regulation of partner preference formation is specific to the dorsomedial NAc shell, the region dense with MORs (Fig. 1), and, perhaps most importantly, that has previously been implicated in positive hedonics (Pecina and Berridge, 2005).

Unlike the dorsal striatum, inhibition of mating-induced partner preferences in the dorsomedial NAc shell was not associated with decreased mating as administration of neither the low

A
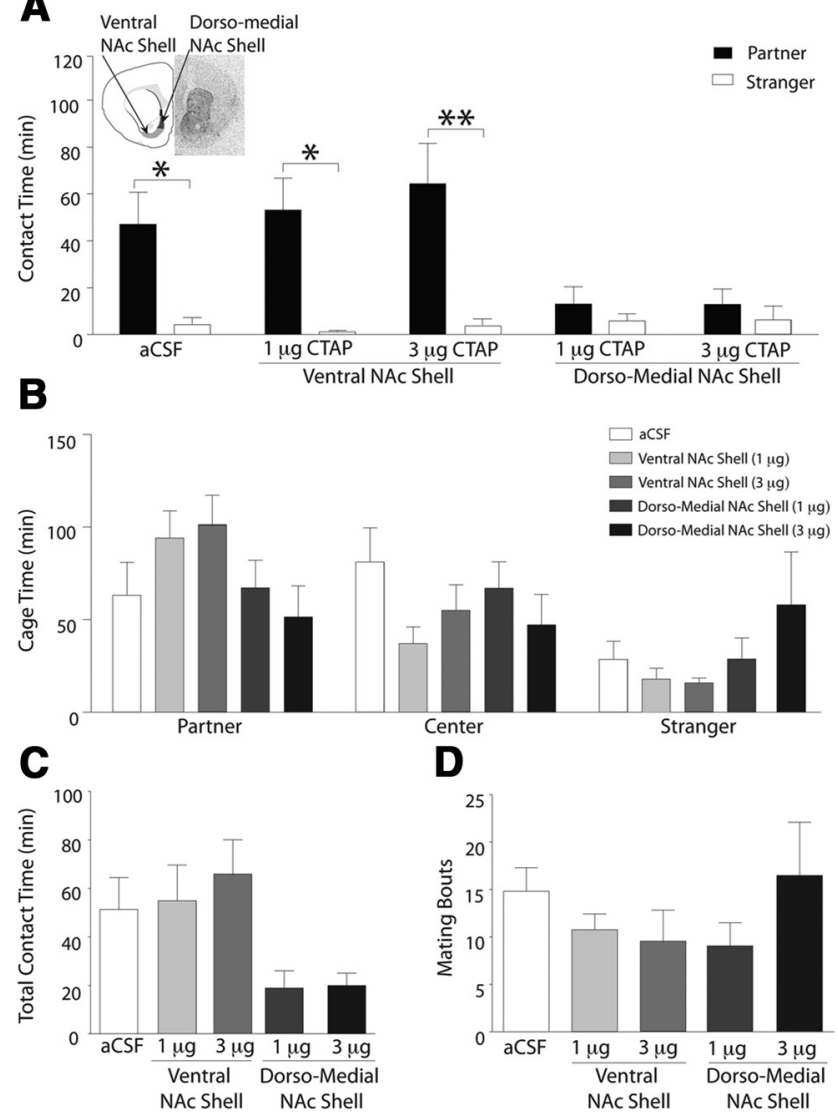

Figure 4. MORs within the dorsomedial, but not ventral, NAc shell are important for partner preference formation. $\boldsymbol{A}$, Site-specific injection of both the low and high dose of CTAP into the dorsomedial NAc shell inhibited partner preference formation, whereas injections of either dose of CTAP were without effect in the ventral NAc shell. Inset, Site of injection into the dorsomedial Nac shell (dark gray) or the ventral NAc shell (light gray) (left) and the binding of MOR within the NAc shell (right). $\boldsymbol{B}-\boldsymbol{D}$, MOR blockade with either dose of CTAP into the NAc shell did not affect $(\boldsymbol{B})$ cage time, $(\boldsymbol{C})$ total contact time (i.e., time spent in contact with the partner + the stranger), or $(\boldsymbol{D})$ the number of mating bouts $(n=4-9) .{ }^{*} p \leq 0.05 .{ }^{* *} p \leq 0.005$.

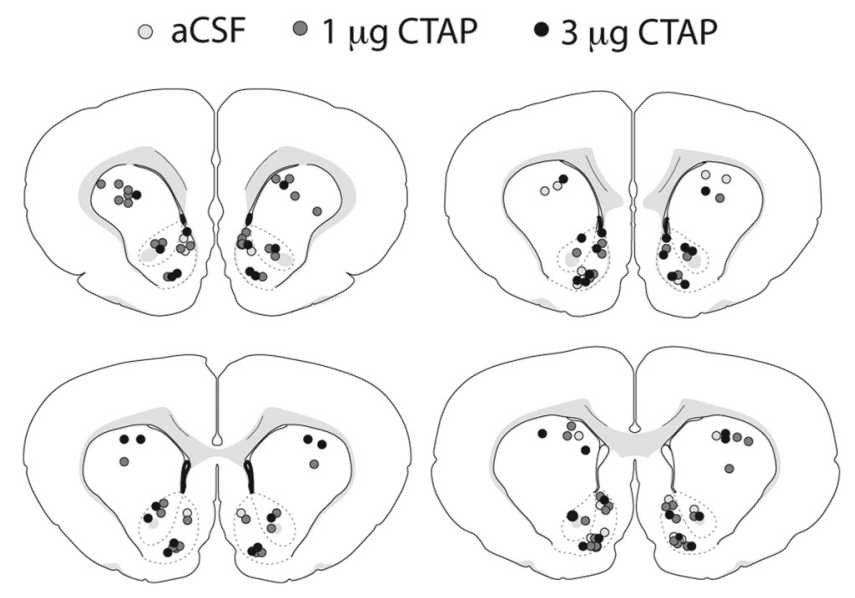

Figure 5. Diagram images representing injection sites of aCSF, $1 \mu \mathrm{g}$ CTAP, or $3 \mu \mathrm{g}$ CTAP into the dorsal striatum, the NAc core, the dorsomedial NAc shell, or the ventral NAc shell.

nor high dose of CTAP within the dorsomedial NAc shell altered the total number of mating bouts $\left(F_{(4,38)}=1.14, p=0.35\right.$; Fig. $4 D$ ) during the cohabitation period. Moreover, because this inhibition of partner preference (via MOR blockade in the dorso- 
medial NAc shell) formation does not act through the regulation of mating behavior but is rather a consequence of mating, these data suggest that MORs within the dorsomedial NAc shell regulate partner preference formation through different psychological mechanisms than those located within the dorsal striatum that directly impact mating behavior, most likely, the positive hedonics associated with mating.

\section{Discussion}

Partner preference formation is a powerful example of social reward, and the current study is among many that show that brain reward circuitry is essential for this behavior (Wang et al., 1999; Gingrich et al., 2000; Aragona et al., 2003; Liu and Wang, 2003; Lim and Young, 2004; Curtis and Wang, 2005a, b; Aragona et al., 2006; Aragona and Wang, 2007; Lim et al., 2007; Burkett et al., 2011; Hostetler et al., 2011; Keebaugh and Young, 2011; Liu et al., 2011). The present study is the first to demonstrate that regional specificity in MORs within the striatum of pair bond formation is the result of different underlying mechanisms associated with social reward.

We first replicated a recent finding (Burkett et al., 2011) by demonstrating that partner preference formation requires activation of MORs within the dorsal striatum, a brain region where MORs mediate motivated behavioral responses (DiFeliceantonio et al., 2012). Additionally, we extend this current knowledge by providing the first evidence that endogenous opioids within the NAc are also critical for partner preference formation; specifically, activation of MORs within the region of the NAc shell implicated in positive hedonics is required for pair bond formation. Importantly, these data provide the first evidence that this dense patch of MORs within the dorsomedial NAc shell not only mediates positive hedonics associated with food reward (Pecina and Berridge, 2000; Smith and Berridge, 2007) but may play a general role in the neural processing of other natural rewards, including social reward. Together, our data identify two potential parallel mechanisms in which MORs regulate partner preference formation: one in which MORs in the dorsal striatum regulate the motivation to engage in mating behavior that facilitates pair bond formation and the second in which MORs in the dorsomedial NAc shell regulate positive hedonic processing that is a consequence of socially rewarding acts, such as mating.

\section{Motivation, the dorsal striatum, and partner preference formation}

Partner preference formation in prairie voles is facilitated by mating (Williams et al., 1992), and the present study demonstrates that blockade of neural systems that mediate this behavior, such as the endogenous opioid system within the dorsal striatum, interferes with the initial formation process. Although opioid regulation of prairie vole mating has only recently been examined (Burkett et al., 2011) and is therefore not well understood, data from other species have directly implicated this system as important for both the act of mating (Coolen et al., 2004; Parra-Gamez et al., 2009; Komisaruk et al., 2010) and the formation of preferences for environments associated with mating (Coria-Avila et al., 2008). During mating, endogenous opioids are released into reward processing regions of the brain (Szechtman et al., 1981), and the release of these peptides is critical for generating sexually motivated responses as peripheral blockade of MORs in rats increases the mating bout interval as well as decreases the frequency of bouts (Ismail et al., 2009). Additionally, the expression of enkephalin, an endogenous ligand for MORs (Simantov et al., 1977), increases in the dorsal striatum of female rats during proestrous (Roman et al., 2006): the period of the estrous cycle where lutenizing hormone and progesterone concentrations surge to induce ovulation, sexual receptivity, and motivation (Smith et al., 1975; Becker, 2009). Together, these results suggest that activation of MORs within the dorsal striatum mediates motivational aspects of sexual behavior.

Indeed, recent evidence from studies of food reward directly implicates MORs within the dorsal striatum in motivated behavior (DiFeliceantonio et al., 2012). Specifically, enkephalin is released in the dorsal striatum during the onset of food consumption, and this release is positively correlated with the speed at which food consumption begins (DiFeliceantonio et al., 2012), indicating that activation of MORs within this region is important for energizing appetitive response to rewarding stimuli (Richard et al., 2013). Therefore, blockade of these receptors while in the presence of a highly salient social stimulus, such as a potential mating partner, may decrease the motivation to seek the reward (i.e., mating). Although it is not possible to objectively measure mating motivation in the present paradigm, lordosis by the female is required for the successful completion of a mating bout, and it is therefore unlikely that dorsal striatal MOR blockade decreased mating through a reduction in sexual mobility (Becker, 2009). However, further studies are necessary to tease apart the direct role of striatal MORs in female mating behavior.

Interestingly, activation of the dorsal striatum is also thought to regulate the motivational aspects of partner preference formation in humans as this region is activated during the early stages of a romantic relationship, but this activation is not correlated with the positive hedonic state induced by the partner (Aron et al., 2005). Similarly, enkephalin released into the dorsal striatum during food consumption is not associated with the hedonic responses to this stimulus (DiFeliceantonio et al., 2012). Thus, activation of MORs within the dorsal striatum appears to be specific to the motivational aspects of reward seeking. In general, these data suggest that MORs within the dorsal striatum may be critical to partner preference formation by generating socially motivated behavioral responses, such as mating, and subsequent consequences of mating, such as partner preference formation.

\section{Positive hedonics, the rostral dorsomedial NAc shell, and partner preference formation}

MORs within the dorsomedial NAc shell have been implicated in positive hedonics (Berridge and Kringelbach, 2008) that is critical in the early stages of attachment formation (Panksepp et al., 1980; Resendez and Aragona, 2013). During the cohabitation period, male and female prairie voles engage in high levels of rewarding social interactions, such as investigatory behavior, mating, and huddling (Carter and Getz, 1993). These interactions are important for the formation of a bond (Williams et al., 1992), and data from the present study demonstrate that blockade of MORs within the dorsomedial NAc shell did not interfere with social contact and mating (i.e., consummatory behavior related to social reward). Instead, removal of a positive hedonic signal after mating by blocking MORs within the dorsomedial NAc shell disrupts social reward and interferes with a positive motivated social decision (Aragona and Wang, 2009; Resendez and Aragona, 2013). These data are consistent with a previous study of social reward that demonstrated that activation of MORs within the NAc shell, and possibly hedonic signaling, is important for guiding socially motivated behavior (Trezza et al., 2011).

A role for hedonics in social bonding is strongly supported by the human literature, and social interactions with a mating partner are indeed described to be pleasurable (Fisher et al., 2006). 
Social interactions with a mate or viewing photos of a romantic love interest activate reward circuitry (Panksepp et al., 2002; Fisher et al., 2006). Together, these data suggest that homologous reward circuits across mammalian species are involved in selective attachment formation. This speaks to the evolution of the role of positive affect in attachment; and given that a common neural circuit may mediate pleasure, our work has implications for a "common neural currency" important for general motivation, including socially motivated behaviors (Cabanac, 2002; Burgdorf and Panksepp, 2006).

\section{Parallel motivational and hedonic processing in partner preference formation}

Appetitive processing within the brain involves interactions between parallel processing striatal circuits associated with cognitive, motor, and limbic regions (Flaherty and Graybiel, 1994; Haber, 2003; Kreitzer and Berke, 2011). With respect to attachment formation, a lack of coupling between consummatory motivated behavior, such as mating, and the subsequent positive hedonic encoding of that behavior may act to decrease future social reward seeking, such as contact with the mated partner during the partner preference test (Resendez and Aragona, 2013). Interestingly, inputs and outputs into the striatum are organized into a topographical, spiral pattern (Haber et al., 2000; Belin et al., 2009) that may account for the regional differences in MOR regulation of pair bond formation within the striatum. Specifically, blockade of MORs in the dorsal striatum may decrease the motivation to generate appropriate motor responses to a salient social stimuli (i.e., reduced mating), whereas those in the dorsomedial NAc shell appear to regulate the positive hedonic coding of that same social stimulus. Thus, coordination between distinct neural systems that differentially code psychological processes of behavior related to social reward is important for attachment formation.

In conclusion, among monogamous prairie voles (Getz et al., 1981), the choice of a mate that will result in successful reproduction is of critical importance (Curtis, 2010; Resendez et al., 2012), and the present study demonstrates that appropriate MOR activation within distinct regions of the striatum has evolved to facilitate social decision making (Resendez and Aragona, 2013). Within the striatum, MORs within dorsal and ventral subregions act in parallel to mediate mating and the hedonic consequences of mating, respectively. Together, the present data and data from studies of food reward indicate that MORs within the striatum do not play a specific role in one type of reward (Berridge and Kringelbach, 2013) but rather act as general neural currency to motivate rewarding/adaptive behavioral responses, including the formation of a selective attachment.

\section{References}

Ahern TH, Young LJ (2009) The impact of early life family structure on adult social attachment, alloparental behavior, and the neuropeptide systems regulating affiliative behaviors in the monogamous prairie vole (Microtus ochrogaster). Front Behav Neurosci 3:17. CrossRef Medline

Aragona BJ, Wang Z (2007) Opposing regulation of pair bond formation by cAMP signaling within the nucleus accumbens shell. J Neurosci 27: 13352-13356. CrossRef Medline

Aragona BJ, Wang Z (2009) Dopamine regulation of social choice in a monogamous rodent species. Front Behav Neurosci 3:15. CrossRef Medline

Aragona BJ, Liu Y, Curtis JT, Stephan FK, Wang Z (2003) A critical role for nucleus accumbens dopamine in partner-preference formation in male prairie voles. J Neurosci 23:3483-3490. Medline

Aragona BJ, Liu Y, Yu YJ, Curtis JT, Detwiler JM, Insel TR, Wang Z (2006) Nucleus accumbens dopamine differentially mediates the formation and maintenance of monogamous pair bonds. Nat Neurosci 9:133-139. CrossRef Medline

Aron A, Fisher H, Mashek DJ, Strong G, Li H, Brown LL (2005) Reward, motivation, and emotion systems associated with early-stage intense romantic love. J Neurophysiol 94:327-337. CrossRef Medline

Bakshi VP, Kelley AE (1993) Feeding induced by opioid stimulation of the ventral striatum: role of opiate receptor subtypes. J Pharmacol Exp Ther 265:1253-1260. Medline

Bales KL, van Westerhuyzen JA, Lewis-Reese AD, Grotte ND, Lanter JA, Carter CS (2007a) Oxytocin has dose-dependent developmental effects on pair-bonding and alloparental care in female prairie voles. Horm Behav 52:274-279. CrossRef Medline

Bales KL, Plotsky PM, Young LJ, Lim MM, Grotte N, Ferrer E, Carter CS (2007b) Neonatal oxytocin manipulations have long-lasting sexually dimorphic effects on vasopressin receptors. Neuroscience 144:38-45. CrossRef Medline

Barrett CE, Keebaugh AC, Ahern TH, Bass CE, Terwilliger EF, Young LJ (2013) Variation in vasopressin receptor (Avpr la) expression creates diversity in behaviors related to monogamy in prairie voles. Horm Behav 63:518-526. CrossRef Medline

Becker JB (2009) Sexual differentiation of motivation: a novel mechanism? Horm Behav 55:646-654. CrossRef Medline

Beery AK, Zucker I (2010) Oxytocin and same-sex social behavior in female meadow voles. Neuroscience 169:665-673. CrossRef Medline

Belin D, Jonkman S, Dickinson A, Robbins TW, Everitt BJ (2009) Parallel and interactive learning processes within the basal ganglia: relevance for the understanding of addiction. Behav Brain Res 199:89-102. CrossRef Medline

Berridge KC, Kringelbach ML (2008) Affective neuroscience of pleasure: reward in humans and animals. Psychopharmacology (Berl) 199:457-480. CrossRef Medline

Berridge KC, Kringelbach ML (2013) Neuroscience of affect: brain mechanisms of pleasure and displeasure. Curr Opin Neurobiol Advance online publication. Retrieved January 30, 2013. doi: 10.1016/j.conb.2013.01.017. CrossRef Medline

Berridge KC, Robinson TE (2003) Parsing reward. Trends Neurosci 26: 507-513. CrossRef Medline

Britt JP, McGehee DS (2008) Presynaptic opioid and nicotinic receptor modulation of dopamine overflow in the nucleus accumbens. J Neurosci 28:1672-1681. CrossRef Medline

Britt JP, Benaliouad F, McDevitt RA, Stuber GD, Wise RA, Bonci A (2012) Synaptic and behavioral profile of multiple glutamatergic inputs to the nucelus accumbens. Neuron 76:790-803. CrossRef Medline

Burgdorf J, Panksepp J (2006) The neurobiology of positive emotions. Neurosci Biobehav Rev 30:173-187. CrossRef Medline

Burkett JP, Spiegel LL, Inoue K, Murphy AZ, Young LJ (2011) Activation of mu-opioid receptors in the dorsal striatum is necessary for adult social attachment in monogamous prairie voles. Neuropsychopharmacology 36:2200-2210. CrossRef Medline

Cabanac M (2002) What is emotion? Behav Processes 60:69-83. CrossRef Medline

Cacioppo JT, Larsen JT, Smith KN, Berntson GG (2004) The affect system: what lurks below the surface of feelings? In: Feelings and emotions: the Amsterdam Symposium (Manstead ASR, Frijda N, Fischer A, eds), pp 223-242. Cambridge: Cambridge UP.

Carter CS, Getz LL (1993) Monogamy and the prairie vole. Sci Am 268:100106. CrossRef Medline

Carter CS, Keverne EB (2002) The neurobiology of social affiliation and pair bonding. In: Hormones, brain, and behavior (Pfaff D, Arnold A, Etgen S, Fahrbach S, Rubin R, eds), pp 299-337. San Diego: Academic.

Cho MM, DeVries AC, Williams JR, Carter CS (1999) The effects of oxytocin and vasopressin on partner preferences in male and female prairie voles (Microtus ochrogaster). Behav Neurosci 113:1071-1079. CrossRef Medline

Coolen LM, Fitzgerald ME, Yu L, Lehman MN (2004) Activation of mu opioid receptors in the medial preoptic area following copulation in male rats. Neuroscience 124:11-21. CrossRef Medline

Coria-Avila GA, Solomon CE, Vargas EB, Lemme I, Ryan R, Ménard S, Gavrila AM, Pfaus JG (2008) Neurochemical basis of conditioned partner preference in the female rat: I. Disruption by naloxone. Behav Neurosci 122:385-395. CrossRef Medline 
Curtis JT (2010) Does fertility trump monogamy? Anim Behav 80:319-328. CrossRef Medline

Curtis JT, Wang Z (2005a) Glucocorticoid receptor involvement in pair bonding in female prairie voles: the effects of acute blockade and interactions with central dopamine reward systems. Neuroscience 134:369-376. CrossRef Medline

Curtis JT, Wang Z (2005b) Ventral tegmental area involvement in pair bonding in male prairie voles. Physiol Behav 86:338-346. CrossRef Medline

Curtis JT, Liu Y, Wang Z (2001) Lesions of the vomeronasal organ disrupt mating-induced pair bonding in female prairie voles (Microtus ochrogaster). Brain Res 901:167-174. CrossRef Medline

Cushing BS, Okorie U, Young LJ (2003) The effects of neonatal castration on the subsequent behavioural response to centrally administered arginine vasopressin and the expression of $\mathrm{V} 1$ a receptors in adult male prairie voles. J Neuroendocrinol 15:1021-1026. CrossRef Medline

Cushing BS, Perry A, Musatov S, Ogawa S, Papademetriou E (2008) Estrogen receptors in the medial amygdala inhibit the expression of male prosocial behavior. J Neurosci 28:10399-10403. CrossRef Medline

Dickinson A, Balleine B (2010) Hedonics: the cognitive-motivational interface. In: Pleasures of the brain (Kringelbach ML, Berridge KC, eds), pp 74-84. New York: Oxford UP.

DiFeliceantonio AG, Mabrouk OS, Kennedy RT, Berridge KC (2012) Enkephalin surges in dorsal neostriatum as a signal to eat. Curr Biol 22: 1918-1924. CrossRef Medline

Donaldson ZR, Spiegel L, Young LJ (2010) Central vasopressin Vla receptor activation is independently necessary for both partner preference formation and expression in socially monogamous male prairie voles. Behav Neurosci 124:159-163. CrossRef Medline

Everitt BJ, Robbins TW (2005) Neural systems of reinforcement for drug addiction: from actions to habits to compulsion. Nat Neurosci 8:14811489. CrossRef Medline

Faure A, Richard JM, Berridge KC (2010) Desire and dread from the nucleus accumbens: cortical glutamate and subcortical GABA differentially generate motivation and hedonic impact in the rat. PLoS One 5:e11223. CrossRef Medline

Fisher HE, Aron A, Brown LL (2006) Romantic love: a mammalian brain system for mate choice. Philos Trans R Soc Lond B Biol Sci 361:2173-2186. CrossRef Medline

Flaherty AW, Graybiel AM (1994) Input-output organization of the sensorimotor striatum in the squirrel monkey. J Neurosci 14:599-610. Medline

Fowler CD, Johnson F, Wang Z (2005) Estrogen regulation of cell proliferation and distribution of estrogen receptor-alpha in the brains of adult female prairie and meadow voles. J Comp Neurol 489:166-179. CrossRef Medline

Gerfen CR (1992) The neostriatal mosaic: multiple levels of compartmental organization. Trends Neurosci 15:133-139. CrossRef Medline

Getz LL, Carter CS, Gavish L (1981) The mating system of the prairie vole, Microtus ochrogaster: field and laboratory evidence for pair bonding. Ecol Sociobiol 8:189-194. CrossRef

Gingrich B, Liu Y, Cascio C, Wang Z, Insel TR (2000) Dopamine D2 receptors in the nucleus accumbens are important for social attachment in female prairie voles (Microtus ochrogaster). Behav Neurosci 114:173183. CrossRef Medline

Graybiel AM (1990) Neurotransmitters and neuromodulators in the basal ganglia. Trends Neurosci 13:244-254. CrossRef Medline

Graybiel AM, Chesselet MF (1984) Compartmental distribution of striatal cell bodies expressing [Met] enkephalin-like immunoreactivity. Proc Natl Acad Sci U S A 81:7980-7984. CrossRef Medline

Haber SN (2003) The primate basal ganglia: parallel and integrative networks. J Chem Neuroanat 26:317-330. CrossRef Medline

Haber SN, Fudge JL, McFarland NR (2000) Striatonigrostriatal pathways in primates form an ascending spiral from the shell to the dorsolateral striatum. J Neurosci 20:2369-2382. Medline

Heinz A, Reimold M, Wrase J, Hermann D, Croissant B, Mundle G, Dohmen BM, Braus DH, Schumann G, Machulla HJ, Bares R, Mann K (2005) Correlation of stable elevations in striatal mu-opioid receptor availability in detoxified alcoholic patients with alcohol craving: a positron emission tomography study using carbon 11-labeled carfentanil. Arch Gen Psychiatry 62:57-64. CrossRef Medline

Herkenham M, Edley SM, Stuart J (1984) Cell clusters in the nucleus ac- cumbens of the rat, and the mosaic relationship of opiate receptors, acteylcholinesterase and subcortical afferent terminations. Neuroscience 11: 561-593. CrossRef Medline

Hostetler CM, Harkey SL, Krzywosinski TB, Aragona BJ, Bales KL (2011) Neonatal exposure to the D1 agonist SKF38393 inhibits pair bonding in the adult prairie vole. Behav Pharmacol 22:703-710. CrossRef Medline

Ikemoto S (2007) Dopamine reward circuitry: two projection systems from the ventral midbrain to the nucleus accumbens-olfactory tubercle complex. Brain Res Rev 56:27-78. CrossRef Medline

Insel TR, Shapiro LE (1992) Oxytocin receptor distribution reflects social organization in monogamous and polygamous voles. Proc Natl Acad Sci U S A 89:5981-5985. CrossRef Medline

Insel TR, Wang ZX, Ferris CF (1994) Patterns of brain vasopressin receptor distribution associated with social organization in microtine rodents. J Neurosci 14:5381-5392. Medline

Ismail N, Girard-Bériault F, Nakanishi S, Pfaus JG (2009) Naloxone, but not flupenthixol, disrupts the development of conditioned ejaculatory preference in the male rat. Behav Neurosci 123:992-999. CrossRef Medline

Johnston JG, Gerfen CR, Haber SN, van der Kooy D (1990) Mechanisms of striatal pattern formation: conservation of mammalian compartmentalization. Brain Res Dev Brain Res 57:93-102. CrossRef Medline

Keebaugh AC, Young LJ (2011) Increasing oxytocin receptor expression in the nucleus accumbens of pre-pubertal female prairie voles enhances alloparental responsiveness and partner preference formation as adults. Horm Behav 60:498-504. CrossRef Medline

Kelley AE, Berridge KC (2002) The neuroscience of natural rewards: relevance to addictive drugs. J Neurosci 22:3306-3311. Medline

Kelley AE, Baldo BA, Pratt WE (2005) A proposed hypothalamic-thalamicstriatal axis for the integration of energy balance, arousal, and food reward. J Comp Neurol 493:72-85. CrossRef Medline

Komisaruk BR, Whipple B, Beyer C (2010) Sexual pleasure. In: Pleasures of the brain (Kringelbach ML, Berridge KC, eds), pp 169-177. New York: Oxford UP.

Kreitzer AC, Berke JD (2011) Investigating striatal function through celltype-specific manipulations. Neuroscience 198:19-26. CrossRef Medline

Lammel S, Ion DI, Roeper J, Malenka RC (2011) Projection-specific modulation of dopamine neuron synapses by aversive and rewarding stimuli. Neuron 70:855-862. CrossRef Medline

Leknes S, Tracey I (2010) Pain and pleasure: masters of mankind. In: Pleasures of the brain (Kringelbach ML, Berridge KC, eds), pp 320-335. New York: Oxford UP.

Lim MM, Young LJ (2004) Vasopressin-dependent neural circuits underlying pair bond formation in the monogamous prairie vole. Neuroscience 125:35-45. CrossRef Medline

Lim MM, Liu Y, Ryabinin AE, Bai Y, Wang Z, Young LJ (2007) CRF receptors in the nucleus accumbens modulate partner preference in prairie voles. Horm Behav 51:508-515. CrossRef Medline

Lim MM, Tsivkovskaia NO, Bai Y, Young LJ, Ryabinin AE (2006) Distribution of corticotropin-releasing factor and urocortin 1 in the vole brain. Brain Behav Evol 68:229-240. CrossRef Medline

Liu Y, Wang ZX (2003) Nucleus accumbens oxytocin and dopamine interact to regulate pair bond formation in female prairie voles. Neuroscience 121:537-544. CrossRef Medline

Liu Y, Aragona BJ, Young KA, Dietz DM, Kabbaj M, Mazei-Robison M, Nestler EJ, Wang Z (2010) Nucleus accumbens dopamine mediates amphetamine-induced impairment of social bonding in a monogamous rodent species. Proc Natl Acad Sci U S A 107:1217-1222. CrossRef Medline

Liu Y, Young KA, Curtis JT, Aragona BJ, Wang Z (2011) Social bonding decreases the rewarding properties of amphetamine through a dopamine D1 receptor-mediated mechanism. J Neurosci 31:7960-7966. CrossRef Medline

Mahler SV, Smith KS, Berridge KC (2007) Endocannabinoid hedonic hotspot for sensory pleasure: anandamide in nucleus accumbens shell enhances "liking" of a sweet reward. Neuropsychopharmacology 32:22672278. CrossRef Medline

Olazábal DE, Young LJ (2006) Oxytocin receptors in the nucleus accumbens facilitate "spontaneous" maternal behavior in adult female prairie voles. Neuroscience 141:559-568. CrossRef Medline

Panksepp J, Herman BH, Vilberg T, Bishop P, DeEskinazi FG (1980) Endogenous opioids and social behavior. Neurosci Biobehav Rev 4:473487. CrossRef Medline 
Panksepp J, Knutson B, Burgdorf J (2002) The role of brain emotional systems in addictions: a neuro-evolutionary perspective and new "selfreport" animal model. Addiction 97:459-469. CrossRef Medline

Parra-Gámez L, García-Hidalgo AA, Salazar-Juárez A, Antón B, Paredes RG (2009) Endomorphin-1, effects on male sexual behavior. Physiol Behav 97:98-101. CrossRef Medline

Peciña S, Berridge KC (2000) Opioid site in nucleus accumbens shell mediates eating and hedonic "liking" for food: map based on microinjection Fos plumes. Brain Res 863:71-86. CrossRef Medline

Peciña S, Berridge KC (2005) Hedonic hot spot in nucleus accumbens shell: where do $\mu$-opioids cause increased hedonic impact of sweetness? J Neurosci 25:11777-11786. CrossRef Medline

Resendez SL, Aragona BJ (2013) Aversive motivation and the maintenance of monogamous pair bonding. Rev Neurosci 24:51-60. CrossRef Medline

Resendez SL, Kuhnmuench M, Krzywosinski T, Aragona BJ (2012) $\kappa$-Opioid receptors within the nucleus accumbens shell mediate pair bond maintenance. J Neurosci 32:6771-6784. CrossRef Medline

Richard JM, Castro DC, DiFeliceantonio AG, Robinson MJF, Berridge KC (2013) Mapping brain circuits of reward and motivation: in the footsteps on Anne Kelley. Neurosci Biobehav Rev Advance online publication. Retrieved December 19, 2012. doi: 10.1016/j.neubiorev.2012.12.008. CrossRef Medline

Roman E, Ploj K, Gustafsson L, Meyerson BJ, Nylander I (2006) Variations in opioid peptide levels during the estrous cycle in Sprague-Dawley rats. Neuropeptides 20:195-206. CrossRef Medline

Simantov R, Childers SR, Snyder SH (1977) Opioid peptides: differentiation by radioimmunoassay and radioreceptor assay. Brain Res 135:358367. CrossRef Medline

Smith KS, Berridge KC (2007) Opioid limbic circuit for reward: interaction between hedonic hotspots of nucleus accumbens and ventral pallidum. J Neurosci 27:1594-1605. CrossRef Medline

Smith KS, Mahler SV, Pecina S, Berridge KC (2010) Hedonic hotspots: generating sensory pleasure in the brain. In: Pleasures of the brain (Kringelbach ML, Berridge KC, eds), pp 27-49. New York: Oxford UP.

Smith MS, Freeman ME, Neill JD (1975) The control of progesterone secretion during the estrous cycle and early pseudopregnancy in the rat: prolactin, gonadotropin and steroid levels associated with rescue of the corpus luteum of pseudopregnancy. Endocrinology 96:219-226. CrossRef Medline

Szechtman H, Hershkowitz M, Simantov R (1981) Sexual behavior decreases pain sensitivity and stimulates endogenous opioids in male rats. Eur J Pharmacol 70:279-285. CrossRef Medline
Trezza V, Damsteegt R, Achterberg EJ, Vanderschuren LJ (2011) Nucleus accumbens $\mu$-opioid receptors mediate social reward. J Neurosci 31: 6362-6370. CrossRef Medline

Vanderschuren LMJ, Everitt BJ (2005) Behavioral and neural mechanisms of compulsive drug seeking. Eur J Pharmacol 5:77-88. CrossRef Medline

Voorn P, Brady LS, Berendse HW, Richfield EK (1996) Densitometrical analysis on opioid receptor ligand binding in the human striatum: I. Distribution of mu opioid receptor defines shell and core of the ventral straitum. Neuroscience 75:777-792. CrossRef Medline

Wang Z, Hulihan TJ, Insel TR (1997) Sexual and social experience is associated with different patterns of behavior and neural activation in male prairie voles. Brain Res 767:321-332. CrossRef Medline

Wang Z, Yu G, Cascio C, Liu Y, Gingrich B, Insel TR (1999) Dopamine D2 receptor-mediated regulation of partner preferences in female prairie voles (Microtus ochrogaster): a mechanism for pair bonding? Behav Neurosci 113:602-611. CrossRef Medline

Watabe-Uchida M, Zhu L, Ogawa SK, Vamanrao A, Uchida N (2012) Whole-brain mapping of direct inputs to midbrain dopamine neurons. Neuron 74:858-873. CrossRef Medline

Watson KK, Sheperd SV, Platt ML (2010) Neuroethology of pleasure. In: Pleasures of the brain (Kringelbach ML, Berridge KC, eds), pp 85-95. New York: Oxford UP.

Williams JR, Carter CS, Insel T (1992) Partner preference development in female prairie voles is facilitated by mating or the central infusion of oxytocin. Ann N Y Acad Sci 652:487-489. CrossRef Medline

Winslow JT, Hastings N, Carter CS, Harbaugh CR, Insel TR (1993) A role for central vasopressin in pair bonding in monogamous prairie voles. Nature 365:545-548. CrossRef Medline

Young LJ, Winslow JT, Nilsen R, Insel TR (1997) Species differences in Vla receptor gene expression in monogamous and nonmonogamous voles: behavioral consequences. Behav Neurosci 111:599-605. CrossRef Medline

Young LJ, Nilsen R, Waymire KG, MacGregor GR, Insel TR (1999) Increased affiliative response to vasopressin in mice expressing the V1a receptor from a monogamous vole. Nature 400:766-768. CrossRef Medline

Young LJ, Murphy Young AZ, Hammock EA (2005) Anatomy and neurochemistry of the pair bond. J Comp Neurol 493:51-57. CrossRef Medline

Zhang M, Kelley AE (2000) Enhanced intake of high-fat food following striatal $\mu$-opioid stimulation: microinjection mapping and fos expression. Neuroscience 99:267-277. CrossRef Medline 